\title{
The COVID-19 Pandemic in Algeria: Lessons and Perspectives
}

\author{
Mohamed Lounis ${ }^{1 *}$
}

${ }^{1}$ University of Djelfa, ALGERIA

*Corresponding Author: lounisvet@gmail.com

Citation: Lounis, M. (2020). The COVID-19 Pandemic in Algeria: Lessons and Perspectives. Aquademia, 4(2), ep20029. https://doi.org/10.29333/aquademia/9137

\section{ARTICLE INFO}

Received: 28 Jul. 2020

Accepted: 11 Aug. 2020

\begin{abstract}
The COVID-19 pandemic has provoked a real mayhem in the world. This "new" situation has shown multiple missing links in different fields such as the health and scientific research. In this way, multiple countries have seen their health systems capacities being stretched while no efficient treatment or vaccine is available until now despite the enormous sums spent in research. This pandemic may serves as a lesson which may push national authorities to "review" their strategies in different fields such as health and scientific research to be prepared for eventual future risks. In this context, missing links, lessons learned from the COVID-19 pandemic in Algeria and perspectives are discussed in this manuscript.
\end{abstract}

Keywords: COVID-19, Algeria, lessons, perspectives

The COVID-19 disease detected first in Wuhan (China); has spread in the world like wild fire provoking a real confusion in the world. Due to its exponential transmission, more than 5.7 millions positive cases were detected leaving until now more than 356,000 dead persons (Johns Hopkins University of Medicine, n.d.).

Algeria, like other countries through the world has not escaped this pandemic respiratory disease. The actual situation shows a number of 8997 positive cases and 630 deaths (Algerian health and hospital reform minister: Carte épidémiologique, n.d.).

This unprecedented situation has posed a new and a major challenge for a developing country as Algeria in the health, the scientific and the educational level.

In the field of health, the Algerian health system is one of the most complex and the most paradoxical in the world. Mainly based on the public sector and managed by the government nationally and regionally, it was considered (with Egypt and South Africa) as the countries with the highest capacity to respond to outbreaks in Africa by a recent modeling study (Gilbert et al., 2020). Also, it occupies a respectable place in terms of medical facilities and staffs, local medical care, vaccination coverage and medical demography taking the fourth range in Africa. With 15 university health institutions and 571public health institutions accounting a total of 82.826 beds with a ratio of 1.9 beds/1000 peoples (Algérie eco, n.d.) (which is higher than the standard recommended by WHO: 1 bed/1000 inhabitant), these numbers are quantitatively better than those of Egypt (1.6) and Morocco (1.1) but lower than those of Tunisia (2.6) in the same region. In terms of human resources, the ratio of 1.83 doctors/1000 persons and 2.24 nurses and midwives/1000 persons are the highest among the Northern African countries (Atlasocio, 2020).

On the other hand, despite the above data and despite the huge sums spent to improve the health system service $(8.5 \%$ PIB), the recent COVID-19 outbreak has in term of quality, left uncovered a weak health system with a lack of adequate diagnostic facilities, and outdated facilities with no proper resources to handle infectious diseases in addition to the luck of means of protection of medical staff. In 2019, Algeria has been ranged among the less prepared countries to respond to health crisis of global importance by the Global Health Security index (Business insider, 2020).

Epidemiologically, the Algerian infectious diseases surveillance system was first adopted since the year 1990 defining notifiable diseases and their declaration. It has later politically committed the adherence to the new International Health Regulation (IHR) 2005 related to all public health emergencies of international concern. This was demonstrated by the adoption of multiple juridical instruments concluded by a presidential decree in 2013 establishing the adoption of the IHR 2005. In this way, The Ministry of public health has put in place a national plan to fight against la H1N1 pandemic in 2009. With some delay, the same actions was adapted and refined for the COVID-19 outbreak. These strategies are limited by a number of essential capacities such as the entry points, health monitoring, response, human resources, specific health hazards and laboratory capacities (Algerian health ministry, n.d.).

Regarding the last point, laboratory analysis was one of the weakest links of Algeria. In the first days, the number of realized test was estimated to only 50 tests per day in the 
Pasteur Institute of Algiers, the only approved laboratory. However, an emergency strategy was conducted by the opening of 20 new laboratories in different departments including university, hospital and research center laboratories, and this number has reached more than 400 tests per day which increased the average number of realized tests to about 200 tests per day since the apparition of the COVID in Algeria (APS (Algerian Press Service), 2020). The official total number still however unknown depicting the weakness of the communication sectors. This weakness is also marked by the luck of clinical information of COVID-19 patients needing more effort to improve the quality of this sector and to ease access to information.

Another important sector is the scientific research. Despite the huge sums accorded to the high education sector the amount reserved to scientific research still weak $(0.9 \%$ of the global budget). The current outbreak has however, demonstrated that the number of scientific initiatives (laboratory analysis, invention of resuscitators, reagents, disinfectors...) are numerous and effecients when possibility arise.

Experimental publications are also rare except the small work of sequencing the virus by the Pasteur Institute but that was published just in the laboratory site (Institut Pasteur d'Algérie, 2020). The current pandemic may push the public and the scientific authorities and researchers to review the political way to improve the scientific research in the country.

At last, another essential point is the health education. The COVID-19 pandemic has shown a low health education characterized by the contempt for the containment measures which were taken lightly by most of the population.

All together, the above points may shake political authorities to review more than one thing in term of health system and scientific research which could be essential in the fighting against possible future emerging risks.

\section{REFERENCES}

Algerian health and hospital reform minister: Carte épidémiologique. (n.d.). Retrieved on 28 May 2020 from https://www.covid19.gov.dz/carte/
Algerian health ministry. (n.d.). Retrieved on 28 May 2020 from http://www.sante.dz/

Algérie eco. (n.d.). Retrieved on 28 May 2020 from http://www.algerie-eco.com/2020/03/22/coronavirus-100millions-usd-pour-accelerer-limportation-de-produitspharmaceutiques/

APS (Algerian Press Service). (2020). Covid-19: hausse sensible du nombre de tests quotidiens dans les laboratoires de l'IPA. Retrieved on 28 May 2020 from http://www.aps.dz/santescience-technologie/104593-covid-19-hausse-sensibledu-nombre-de-tests-quotidiens-dans-les-laboratoiresde-1-ipa

Atlasocio. (2020). Classement des Etats du monde par nombre de lits medicalises pour 1000 habitats. Retrieved on 15 May 2020 from https://atlasocio.com/classements/sante/ infrastructures/classement-etats-par-nombre-de-litsmedicalises-pour-1000-habitants-monde.php

Business insider. (2020). Global Health Security Index to assess the health security of 195 countries. Retrieved on 15 May 2020 from https://www.ghsindex.org/wp-content/ uploads/2019/10/2019-Global-Health-Security-Index.pdf

Gilbert, M., Pullano, G., Pinotti, G., Valdano, E., Poletto, C., Boëlle, P. Y., D’Ortenzio, E., Yazdanpanah, Y., Eholie, S. P., Altmann, M., Gutierrez, B., Kraemer, M. U. G., \& Colizza, V. (2020). Preparedness and vulnerability of African countries against importations of COVID-19: a modelling study. Lancet, 395(10227), 871-877. https://doi.org/ 10.1016/S0140-6736(20)30411-6

Institut Pasteur d'Algérie. (2020). Premières analyses de séquences des souches algériennes de SARS-COV-2. Retrieved on 28 May 2020 from https://pasteur.dz/fr/dz/ 285-premieres-analyses-de-séquenes-des-souchesalgeriennes-de-sars-cov-2

Johns Hopkins University of Medicine, Coronavirus resource center. (2020). COVID-19 Dashboard by the Center for Systems Science and Engineering (CSSE) at Johns Hopkins University (JHU). Retrieved on 28 May 2020 from https://coronavirus.jhu.edu/map.html 